\title{
Determinants of Internet use for interactive learning: an exploratory study
}

\author{
Jonatan Castaño ${ }^{1 *}$, Josep M. Duart ${ }^{2}$, Teresa Sancho-Vinuesa ${ }^{3}$ \\ ${ }^{1}$ E-Learn Center, Universitat Oberta de Catalunya (UOC) \{jcastanomu@uoc.edu\} (it) \\ ${ }^{2}$ E-Learn Center, Universitat Oberta de Catalunya (UOC) \{jduart@uoc.edu\} (D) \\ ${ }^{3}$ E-Learn Center, Universitat Oberta de Catalunya (UOC) \{tsancho@uoc.edu\} (D) \\ Received on 26 February 2014; revised on 3 March 2014; accepted on 22 April 2014; published on 15 January 2015
}

DOI: 10.7821/naer.2015.1.93

\begin{abstract}
The use of the Internet in higher education teaching can facilitate the interactive learning process and thus improve educational outcomes. The aim of the study presented here is to explore which variables are linked to higher intensity of Internet-based interactive educational practices. The study is based on data obtained from an online survey of students from three different types of universities: a face-to-face university (University of Barcelona, UB), a technological face-to-face university (Universitat Politècnica de Catalunya. BarcelonaTech, UPC), and a virtual university (Open University of Catalonia, UOC). The data analysis shows that students who indicate high levels of benefit from Internet usage are those who use it most for interactive learning processes. It also shows the existence of other variables that, regardless of benefit, are linked to the intensity of Internet usage for interactive teaching-learning processes.
\end{abstract}

KEYWORDS: HIGHER EDUCATION, INTERNET, INTERACTIVE LEARNING, VIRTUAL LEARNING, BLENDED LEARNING.

\section{INTRODUCTION: DIGITAL DIVIDE AND DETERMINANTS OF INTERNET USE FOR INTERACTIVE LEARNING}

The digital breach theory reveals the possible risks to social equality entailed in the implementation and broadening of Internet usage (DiMaggio, Hargittai, Celeste \& Shafer, 2004; Hargittai \& Walejko, 2008; Robles-Morales, Torres-Albero, \& Molina-Molina, 2010; van Dijk, 2005; Zillien \& Hargittai, 2009). The fact that there are uses that offer competitive advantages and added value to those individuals that employ them is positive at first glance. However, it is also a source of inequality among individuals and puts the individuals that do not employ them at a disadvantage.

In education, the Internet can provide support in various types of learning: expository, active, and interactive (Means, Toyama, Murphy, Bakia \& Jones, 2009). However, the literature has been more concerned with studying which variables determine general Internet usage in education, than it has been with researching the specific determinants of Internet usage for each one of these types of learning in particular.

What is especially surprising about this lack of research is the

${ }^{*}$ To whom correspondence should be addressed:

Universitat Oberta de Catalunya

Rambla Poblenou,156 / 08018 Barcelona, Spain dearth of more specific analyses of Internet determinants for interactive learning, since online interaction is considered an important skill to acquire in 21st century societies, and at the same time one of the greatest potentialities of Internet usage in the teaching-learning process (Beauchamp \& Kennewell, 2010; Wilson \& Stacey, 2003; Zhao, Lei, Yan, Lai \& Tan, 2005). In particular, Internet usage for interactive learning has proven to be an effective tool in improving the academic performance of face-to-face and virtual education students (Bernard et al., 2009; Castaño-Muñoz, 2011; Castaño-Muñoz, Duart \& SanchoVinuesa, 2014).

Thus, the fact that certain individuals use the Internet for interactive learning and others do not means that the former have better learning results. In the same manner, certain universities, departments, or degree plans placing a much higher emphasis on interactive Internet uses may give rise to inequality between the students whose institutional framework encourages these uses and those that study in environments that do not. It is therefore important to ask what determines that certain students employ this interaction more intensely than others.

Studies on technology have reached a certain consensus that individuals, more than exploring the new possibilities that technology offers, tend to use it to do things they already did without it, but more effectively and/or extensively (DiMaggio et al., 2004). Therefore, with this premise in mind, it makes sense to think that one of the determinants of Internet usage for interactive learning is the type of Internet usage the student employs, including both those involving the use of technology in education and those involving interactive learning that does not use the Internet in the process.

Moreover, based on the literature regarding the adoption of technology (Davis, 1989; Davis \& Venkatesh, 2003), it may be expected that those students that benefit most from interactive Internet usage (Castaño-Muñoz, Sancho-Vinuesa, \& Duart, 2012) will also be those that use it most intensely, since they obtain a greater benefit. However, there may be other factors beyond benefit that have an effect on use, and an exploratory study on the determinants of Internet usage for interactive learning is therefore necessary.

\section{OBJECTIVE AND STUDY METHOD}

The objective of this article is to provide elements that contribute to advancing the knowledge of the variables linked to Internet usage for interactive learning. Following the digital 
breach line of research, which links the variables of the individuals and their surroundings to Internet uses, we aim to answer the following question: Which individual variables, academic environments, and non-academic Internet uses are linked to higher intensity of Internet-based interactive educational practices?

Providing an answer to these questions is useful in finding out which students are taking most advantage of the Internet in education, and thus also in finding out which students are missing educational opportunities in this information society.

\subsection{Participants and data collection procedure}

In order to answer the question being researched, the study has focused on the analysis of students from three universities of differing characteristics: the University of Barcelona (UB) as a general university, the Universitat Politècnica de Catalunya (UPC) as a technical university, and Open University of Catalonia (UOC) as a distance-learning university. Each of the universities analyzed has a different student profile, thus making the sample more varied.

Data collection was carried out by means of an online survey questionnaire sent to the university's institutional email. Thus, the sample analyzed is a self-selected sample of students that largely excludes students that do not use the Internet or that have discontinued their studies (and therefore do not use the university's email). A total of 17,090 individuals responded from the three universities.

\subsection{Variables and analytical model}

In order to find out which variables are linked to Internet usage for interactive learning, three multiple linear regression models were carried out, one for the face-to-face universities, one for the virtual, and one for the combination of all three. This will allow us to observe whether there are differences according to study program.

The independent variable of the proposed models is the degree of Internet usage for interactive learning undertaken by active students and Internet users at the universities studied. In order to construct an indicator of the degree of online interaction to measure online interaction, we used a battery of dichotomous questions asking about Internet usage for communication with professors, communication with classmates, participation in online discussions, and Internet use as a tool for co-operative work. The result is a variable with a minimum of zero uses and a maximum of four.

In the models presented, the intensity of Internet usage for interactive learning thus measured is posited as a function of a vector of the students' socio-demographic characteristics, a vector of variables involving the student's position in the digital breach and his/her relation to technology, including his/her purposes for use, a vector of characteristics of the studies currently underway, and a vector of variables that, together with the socio-demographic ones, help control the possible bias stemming from not having a direct measurement of the time available to continue his/her studies. The model may be specified in the following way.

$$
\mathrm{UII}_{\mathrm{i}}=\Sigma \mathrm{b}_{\mathrm{j}} \mathrm{X}_{\mathrm{ij}}+\Sigma \mathrm{d}_{\mathrm{m}} \mathrm{BD}_{\mathrm{im}}+\Sigma \mathrm{c}_{\mathrm{k}} \mathrm{Est}_{\mathrm{ik}}+\Sigma \mathrm{T}_{\mathrm{in}}+\varepsilon
$$

Where:

$\mathrm{UII}_{\mathrm{i}}=$ The number of interactive uses that the student employs. (From 0 to 4 )
$\mathrm{X}_{\mathrm{ij}}=\mathrm{a} \mathrm{j}$ vector of the students' characteristics: Age, gender (male/female). Two classical variables in the study of determinants of Internet uses.

$\mathrm{BD}_{\mathrm{im}}=\mathrm{a}$ vector of variables involving the dimensions of the digital breach, and that the literature clearly marks as linked to the usage employed. This category includes Internet usage in education for information searches.

1 dummy variable separating the students that are better situated in the classical digital breach from those that are poorly situated, without taking into account the purposes of use. This variable is called Digital leaders and it is the product of the previously presented cluster analysis.

A series of variables involving Internet uses for non-academic purposes.

For academic uses, the Internet usage variable was used for individual information searches in learning, considering it as continuous, since it has more than 5 categories.

$\mathrm{Est}_{\mathrm{ik}}=\mathrm{a}$ set of fictitious or dummy variables referring to the type of studies the student is undertaking, and his/her position in them:

3 dummy variables differentiating the student's study program: $100 \%$ virtual, $100 \%$ face-to-face, or a hybrid. The hybrid category is considered to contain all students from the face-to-face program that have followed some course with online content, although not necessarily all of them. It will therefore only be included in the regressions containing students from the face-to-face program.

10 dummy variables differentiating the department corresponding the student's degree plan: Psychology and education, Computer engineering, Other engineering and architecture, Humanities, Documentation and information, Economy and company, Law and political sciences, Health sciences, Exact and natural sciences, and Other social sciences.

3 dummy variables distinguishing the type of degree plan the student is pursuing: diploma of higher education, Bachelor's or Engineer's degree or second-term.

1 continuous variable measuring the experience as students, and how close he/she is to completing his/her studies: Accumulated credits earned up to the studied course.

$\mathrm{T}_{\text {in }}=\mathrm{A}$ vector of variables used as proxies, together with socio-demographic variables, to avoid possible biases as a result of not observing directly, and the time dedicated to each course: Enrolled credits during the course and student's work status.

$\varepsilon=$ error term

The variables presented in the model have the function of providing a general panorama of determinants of Internet usage for interactive learning, but also of controlling the possible biases in the estimates of the connection between this use of the variables that we want to study more in-depth, and those with a benefit-based hypothesis.

It should be noted that the university variable was not incorporated into the implemented models, given its high correlation with the variables above. This correlation is due to the fact that students that study $100 \%$ online are exclusively those studying at UOC, and to the fact that almost all of the UPC students are in the engineering department. 
Due to the nature of the data being dealt with, the individuals are grouped into multiple analytical levels (University, department, and type of study), and this may cause problems in the estimates because it violates the supposition of the individuals' independence resulting from the intra-class correlation.

In order to solve this problem in the models presented, we have opted to vigorously calculate the standard errors, applying a cluster correction. This correction uses as primary units the 49 groups resulting from the combination of the university, field of study, and type of degree plan variables (first-term, first and second-term, or second-term only).

\section{RESULTS}

Table 1 presents the three estimated multiple linear regression models to achieve the described objective of this article. The first model is for the combination of all of the universities studied, the second for the face-to-face universities (UB and UPC), and the third for the virtual University (UOC) only. This separation will allow us to describe the general trends, as well as identify the differences between virtual and face-to-face education.

In keeping with other studies on Internet uses, our data link the youngest students to higher Internet usage, especially for communication and interaction (Premsky, 2001). The analyses performed show that older age is linked, as a quadratic function, to lower Internet usage for interactive learning. Introducing the quadratic function allows us to see that the older an individual is, the lesser the effect of age on the intensity of Internet usage for interactive learning. In the specific analysis of the virtual program, the dearth of students in the younger age groups, where age has a greater effect, causes the age variable to lose significance in explaining this Internet usage in virtual education. The model's quadratic correlation seems to indicate that, ceteris paribus, a culture of communication and interaction using the Internet is more widespread among the youngest students, extending also to the academic field, whereas starting at a specific age or generation there are no significant differences.

In terms of gender, the estimates show that it is a significant variable, although with little weight in terms of explaining Internet usage for interactive learning. Women are the gender that uses the Internet most for interactive learning at the virtual university, with an estimate of 0.103 uses more than men from this same university. However, this is not the case for female students at the face-to-face universities, and the model does not allow us to establish any effect of gender on the degree of Internet usage for academic interaction. Considering the average age of both universities, this fact is in keeping with certain studies that posit that the digital gender breach is being reduced among the youngest individuals (OECD, 2007) and that at these ages there are fewer differences in the uses employed among genders than there are at more advanced ages.

The proposed models allow us to identify a weak correlation between working and higher Internet usage for interactive learning. And this, even while controlling the number of enrolled credits, which is logically lower for students that work (an average of 9 fewer credits in the case of the virtual program, and of almost 8 in the program at the face-to-face universities). We observed that, taking the population as a whole, working is significantly linked to higher Internet usage for learning, at a significance level of $90 \%$, estimating 0.032 more points on the usage intensity scale for working students. This same trend is seen in the face-to-face universities. However, in the specific analysis of the virtual program, no statistically significant correlation is observed, given that only $3.8 \%$ of students from our sample do not work, and therefore the confidence interval is extremely broad for this group.

The work variable is linked to a lack of time for study, but it is not the only one. The student's course load may also be a proxy for finding out the available study time if the rest of the variables remain steady. Once again, there is a significant but not very high correlation that indicates that the heavier the student's course load, the higher the Internet usage for interactive learning.

Considering work and enrolled credits as proxies of the available study time, the results indicate that, ceteris paribus, in the case of students of face-to-face universities, having less time for study is a factor that favors higher Internet usage for interactive learning. It therefore seems that the effect of having less available study time on interactive Internet usage is less than that of the need to more effectively take advantage of time and to be able to fit in the necessary Internet-based interactive learning. This makes sense when we consider that individuals with more time may undertake their learning more conveniently, and therefore may need less help from others, whereas those with less available time need interaction in order to be at the same level.

\section{DISCUSSION}

\subsection{Student-technology correlation variables}

As expected within the set of individual variables, it is not only the students' socio-demographic characteristics that are linked to Internet uses for interactive learning. The student's relation to technology is also linked to this use.

The proposed models allow us to confirm the existence of a positive link between having high usage abilities (digital leaders), and higher Internet usage for interactive learning. Taking the entirety of the students analyzed, this effect is 0.1 points higher on the intensity scale. However, the results show that having high usage abilities has a different effect according to the study program in which the student is pursuing his/her degree. For example: in the online program, the effects of being a digital leader are not statistically significant in terms of explaining higher or lower Internet usage for collaborative learning. On the contrary, being a leader at a face-to-face university, (whether or not the program is accompanied by online courses) is significant. The spot estimate is approximately 0.117 more uses in the case of the face-to-face university students. These data allow us to detect a breach among students with better Internet usage abilities than the rest. However, this breach in Internet usage for interactive learning does not occur at institutions that encourage more interaction as part of their teaching methodology, at which all students use it equally.

In order to interpret these data in terms of benefit, it is important to remember that in previous studies with the same database (Castaño Muñoz et al., 2012), it has been shown that digital leaders actually receive more benefits from interaction in the online program, where the environment in which to untertake it is more technological (See Table 2). 
Table 1. Determinants of Internet Use for interactive learning (listed by program)

\begin{tabular}{|c|c|c|c|}
\hline & All & Face-to-Face & Virtual \\
\hline Virtual program & $\begin{array}{l}1.072^{* * * *} \\
(0.08)\end{array}$ & & \\
\hline Age & $\begin{array}{l}-0.045^{* * *} \\
(0.01)\end{array}$ & $\begin{array}{l}-0.047 * * * \\
(0.01)\end{array}$ & $\begin{array}{l}-0.010 \\
(0.02)\end{array}$ \\
\hline Age2 & $\begin{array}{l}0.001^{* * * *} \\
(0.00)\end{array}$ & $\begin{array}{l}0.001^{* * * *} \\
(0.00)\end{array}$ & $\begin{array}{l}0.000 \\
(0.00)\end{array}$ \\
\hline Work & $\begin{array}{l}0.032 * \\
(0.02)\end{array}$ & $\begin{array}{l}0.036^{* *} \\
(0.02)\end{array}$ & $\begin{array}{l}0.044 \\
(0.05)\end{array}$ \\
\hline Gender & $\begin{array}{l}0.050 * \\
(0.03)\end{array}$ & $\begin{array}{l}0.033 \\
(0.04)\end{array}$ & $\begin{array}{l}0.103^{* * *} \\
(0.02)\end{array}$ \\
\hline Online course experience & $\begin{array}{l}0.428 * * * \\
(0.02)\end{array}$ & $\begin{array}{l}0.426^{* * *} \\
(0.02)\end{array}$ & \\
\hline Bachelor's or Engineer's degree(4 years) & $\begin{array}{l}-0.319 * * * \\
(0.06)\end{array}$ & $\begin{array}{l}-0.346^{* * *} \\
(0.08)\end{array}$ & $\begin{array}{l}-0.275^{* * *} \\
(0.04)\end{array}$ \\
\hline Diploma (3 years) & $\begin{array}{l}-0.070 \\
(0.06)\end{array}$ & $\begin{array}{l}-0.067 \\
(0.08)\end{array}$ & $\begin{array}{l}-0.108 \text { *** } \\
(0.03)\end{array}$ \\
\hline Psychology and education & $\begin{array}{l}0.349 * * \\
(0.14)\end{array}$ & $\begin{array}{l}0.211 \\
(0.14)\end{array}$ & $\begin{array}{l}0.510 * * * \\
(0.05)\end{array}$ \\
\hline Other Engineering & $\begin{array}{l}-0.221^{* *} \\
(0.10)\end{array}$ & $\begin{array}{l}-0.336^{* * *} \\
(0.06)\end{array}$ & \\
\hline Humanities & $\begin{array}{l}-0.354^{* * *} \\
(0.11)\end{array}$ & $\begin{array}{l}-0.517^{* * *} \\
(0.08)\end{array}$ & $\begin{array}{l}-0.061 \\
(0.05)\end{array}$ \\
\hline Documentation and information & $\begin{array}{l}-0.148 \\
(0.11)\end{array}$ & $\begin{array}{l}-0.150 \\
(0.11)\end{array}$ & $\begin{array}{l}-0.156^{* * *} \\
(0.03)\end{array}$ \\
\hline Economy and company & $\begin{array}{l}-0.411^{* * *} \\
(0.10)\end{array}$ & $\begin{array}{l}-0.550^{* * *} \\
(0.09)\end{array}$ & $\begin{array}{l}-0.201^{* * *} \\
(0.02)\end{array}$ \\
\hline Law and Political Sciences & $\begin{array}{l}-0.307^{* * * *} \\
(0.10)\end{array}$ & $\begin{array}{l}-0.342^{* * *} \\
(0.07)\end{array}$ & $\begin{array}{l}-0.293^{* * *} \\
(0.05)\end{array}$ \\
\hline Health sciences & $\begin{array}{l}-0.142 \\
(0.11)\end{array}$ & $\begin{array}{l}-0.226^{* * *} \\
(0.08)\end{array}$ & \\
\hline Exact and natural sciences & $\begin{array}{l}-0.338^{* * *} \\
(0.09)\end{array}$ & $\begin{array}{l}-0.424^{* * *} \\
(0.06)\end{array}$ & \\
\hline Other Social Sciences & $\begin{array}{l}-0.134 \\
(0.08)\end{array}$ & $\begin{array}{l}-0.223^{* * *} \\
(0.06)\end{array}$ & \\
\hline Currently enrolled credits in the course & $\begin{array}{l}0.002^{* *} \\
(0.00)\end{array}$ & $\begin{array}{l}0.002 * \\
(0.00)\end{array}$ & $\begin{array}{l}0.003^{* *} \\
(0.00)\end{array}$ \\
\hline Accumulated credits earned (without course) & $\begin{array}{l}0.001^{* * *} \\
(0.00)\end{array}$ & $\begin{array}{l}0.001^{* *} \\
(0.00)\end{array}$ & $\begin{array}{l}0.001 * \\
(0.00)\end{array}$ \\
\hline Digital leader & $\begin{array}{l}0.100^{* * *} \\
(0.02)\end{array}$ & $\begin{array}{l}0.117^{* * *} \\
(0.02)\end{array}$ & $\begin{array}{l}0.041 \\
(0.03)\end{array}$ \\
\hline Downloads & $\begin{array}{l}0.040^{* * *} \\
(0.01)\end{array}$ & $\begin{array}{l}0.042^{* * *} \\
(0.01)\end{array}$ & $\begin{array}{l}0.024^{* *} \\
(0.01)\end{array}$ \\
\hline Relations & $\begin{array}{l}0.061^{* * *} \\
(0.01)\end{array}$ & $\begin{array}{l}0.052^{* * *} \\
(0.01)\end{array}$ & $\begin{array}{l}0.080^{* * *} \\
(0.02)\end{array}$ \\
\hline Web 2.0 & $\begin{array}{l}0.086^{* * * *} \\
(0.01)\end{array}$ & $\begin{array}{l}0.094 * * * \\
(0.01)\end{array}$ & $\begin{array}{l}0.062^{* * *} \\
(0.01)\end{array}$ \\
\hline Basic uses & $\begin{array}{l}0.090^{* * *} \\
(0.01)\end{array}$ & $\begin{array}{l}0.113^{* * *} \\
(0.02)\end{array}$ & $\begin{array}{l}0.045^{* * *} \\
(0.01)\end{array}$ \\
\hline Commerce & $\begin{array}{l}0.039 * * * \\
(0.01)\end{array}$ & $\begin{array}{l}0.053^{* * *} \\
(0.01)\end{array}$ & $\begin{array}{l}0.000 \\
(0.01)\end{array}$ \\
\hline Work & $\begin{array}{l}0.112^{* * *} \\
(0.01)\end{array}$ & $\begin{array}{l}0.139^{* * *} \\
(0.01)\end{array}$ & $\begin{array}{l}0.045^{* * *} \\
(0.01)\end{array}$ \\
\hline Internet search for academic information & $\begin{array}{l}0.237^{* * *} \\
(0.02)\end{array}$ & $\begin{array}{l}0.191^{* * *} \\
(0.01)\end{array}$ & $\begin{array}{l}0.351^{* * *} \\
(0.02)\end{array}$ \\
\hline Constant & $\begin{array}{l}1.915^{* * * *} \\
(0.22)\end{array}$ & $\begin{array}{l}2.260 * * * \\
(0.16)\end{array}$ & $\begin{array}{l}1.780 * * * \\
(0.34)\end{array}$ \\
\hline R2 & 0.305 & 0.245 & 0.195 \\
\hline Adjusted R2 & 0.304 & 0.242 & 0.193 \\
\hline $\mathrm{N}$ & 17.087 & 8.046 & 9.041 \\
\hline
\end{tabular}

Source: In-house report

$* * *$ significant at $99 \% * *$ significant at $95 \% *$ significant at $90 \%$ 
Table 2. Benefit-Use comparison according to students’ Internet abilities

\begin{tabular}{lcc}
\hline & Added benefit & Extra use \\
\hline Face-to-Face program & NO & YES \\
Virtual program & YES & NO \\
\hline
\end{tabular}

Source: In-house report

Therefore, we cannot declare that the extra benefit of the digital leaders is an incentive for higher usage, since the benefitbased usage hypothesis is not confirmed, but rather the dynamic is the following:

In the face-to-face program, where interaction is less encouraged and less integrated into the evaluation, and where less sophisticated tools are therefore used, the digital leaders use the Internet more for interaction. In this manner they break with the limitations and restrictions imposed by the teaching-learning system. However, the system does not especially acknowledge more sophisticated use in the form of academic performance benefits. The system only values the elements it includes, which are the most basic elements. We see therefore that higher use is separate from benefit.

In the virtual model, where interaction is strongly integrated in the teaching-learning processes and more sophisticated tools are used, the digital leaders have the same intensity of interactive practices. This is so because in a certain way the teaching-learning system requires all students to employ a high number of uses. However, the digital leaders in this environment of highly integrated technology for integration are capable of achieving added benefit with the same number of uses as the rest. That is, digital leaders do not benefit more from the intensity of Internet usage for interactive learning, but they do benefit from the higher level of sophistication they can achieve, which is acknowledged in virtual universities.

Now in terms of what is considered the latest and most important dimension of the digital breach: the differing uses of the Internet (Van Dijk \& Hacker, 2003; van Dijk, 2005), and assuming that extracurricular Internet uses begin before entering into the university (the average beginning age of the face-to-face university students from our analysis is between 16 and 17 years old), and that people tend to adopt technology to reproduce what they were already doing previously in other environments (DiMaggio et al., 2004), it may be argued that the habits acquired in the usage trajectory prior to university are important factors in determining the level and purpose of Internet usage in education.

This assumption appears to be confirmed in the analysis of the correlation between the differing uses of individuals, and Internet usage for interactive learning. Our data demonstrate that higher Internet usage outside of the classroom is linked to higher Internet usage for interactive learning, since when the population is taken as a whole, all of the uses studied are significant in terms of explaining said link, and they are interrelated positively. The only exception is use for e-commerce in the case of the virtual program students.

Despite this positive and almost total correlation between the uses outside of the formal teaching-learning process and Internet usage for interactive learning, there are some differences in regard to the degree of association. Two groups were formed according to the degree of influence on Internet-based interaction. The criteria for this formation consisted of placing all uses whose influence is not statistically significant in the group most linked to Internet usage, with the other group representing usage with a higher spot estimate.

In both programs, Internet uses for work, the most basic uses (information search and email), and the use of web 2.0 make up the group of uses most linked to higher Internet usage for interactive learning. The first of this group is characterized by its formal component, people whose Internet usage style is less focused on leisure and who use the Internet for work. They use interactive Internet possibly because they are already accustomed to doing so at work and it is an extension of interactive Internet usage for their duties, whether occupational or academic. The second use includes email usage among the basic uses, and this widely used tool is without a doubt one of the main ones in terms of communicating with classmates and professors. Finally, web 2.0 is the use most linked to interactive learning, and while in 2005 it was a minor use and social networks had not yet become widely available, doing things such as blogging, posting information to share, and receiving information via RSS fits the profile of an interactive student that shares the philosophy of web 2.0 and online and interactive learning.

Likewise, in both programs, Internet uses for e-commerce and for downloading information are not very linked to Internet usage for interactive learning. This is explained by the fact that the these two uses have a chiefly leisure component and do not involve any type of interaction.

On the other hand, the only variable that does not coincide in both programs is the one involving the uses most associated with the use being studied: the use of the internet for relations, which has a communicative component linked to interaction, but also a strong leisure component. In this sense, it is surprising to see that this use belongs to the group of most associated uses in the case of virtual program students, which is the group with the higher spot estimate, and to the group of least associated uses in the case of face-to-face universities. This phenomenon may be explained by the degree to which the communications are leisure-oriented. Given that this use involves using the Internet to chat, use instant messaging services, and meet and/or date people, it makes sense to think that interaction using these media is more leisure-oriented in a younger student type such as that of the face-to-face university, and less leisure-oriented in a more adult student type such as that of the virtual university. Table 3 summarizes the correlations between extracurricular uses and Internet-based interactive learning.

Table 3. Relation of extracurricular groups to interactive Internet use in education

\begin{tabular}{lll}
\hline & $\begin{array}{l}\text { Face-to-Face } \\
\text { program }\end{array}$ & $\begin{array}{l}\text { Virtual pro- } \\
\text { gram }\end{array}$ \\
\hline $\begin{array}{l}\text { Uses most related to interac- } \\
\text { tive learning }\end{array}$ & Work & Relations \\
& Basic uses & Web 2.0 \\
& Web 2.0 & Work \\
& & Basic uses \\
\hline $\begin{array}{l}\text { Uses least related to interac- } \\
\text { tive learning }\end{array}$ & $\begin{array}{l}\text { Commerce } \\
\text { Relations }\end{array}$ & $\begin{array}{l}\text { Downloads } \\
\text { Commerce }\end{array}$ \\
\hline
\end{tabular}

Source: In-house report

Therefore, we can confirm that using the Internet for certain uses outside of the classroom has positive effects on Internet usage for interactive learning [sic]. This result displays the 
importance of informal digital skills, and shows that some Internet uses outside of the classroom may indirectly have positive effects on academic performance.

\subsection{Institutional variables}

It is clear that studying in one educational program or another is the most important variable in terms of explaining interactive Internet usage for academic purposes. We clearly observe how studying in a $100 \%$ online program is the most determinant factor in terms of having a higher number of interactive Internet uses, with the students in this program having approximately one use more than those in the face-to-face program. This makes sense, since the students in this program have only the Internet for their interactive teaching-learning process. On the other hand, we see that within the face-to-face universities, having some type of experience in courses that use the Internet as an aid to the teaching-learning process is a key determinant in terms of calculating the intensity of interactive Internet usage upon continuing studies.

The analysis of the differences in Internet usage for interactive learning by fields of study shows some common traits and some differences when comparing the face-to-face and virtual universities. The data from this analysis must be interpreted as separate from the characteristics of the students, and from the degree to which their studies are career-oriented.

After performing the test for equality of the estimated betas, the fields of study can be put into 4 differing groups according to Internet usage for interactive learning. Each group has Internet usage that is uniform among itself and different than the rest at a 95\% confidence interval. In order to interpret the groups, it is important to point out that they are formed according to the uses of the other departments of the same program.

Table 4 shows a summary of the 4 groups separated by study program.

Table 4. Groups according to interactive Internet usage for education

\begin{tabular}{lll}
\hline High & Face-to-Face & Virtual \\
& $\begin{array}{l}\text { Psychology and educa- } \\
\text { tional sciences } \\
\text { Computer Engineering }\end{array}$ & $\begin{array}{l}\text { Psychology and educa- } \\
\text { tional sciences }\end{array}$ \\
\hline $\begin{array}{l}\text { Medium- } \\
\text { High }\end{array}$ & $\begin{array}{l}\text { Documentation and infor- } \\
\text { mation }\end{array}$ & $\begin{array}{l}\text { Computer Engineering } \\
\text { Humanities }\end{array}$ \\
& $\begin{array}{l}\text { Other social sciences } \\
\text { Health sciences }\end{array}$ & \\
\hline Modium- & $\begin{array}{l}\text { Other engineering } \\
\text { Law and political sciences }\end{array}$ & $\begin{array}{l}\text { Documentation and } \\
\text { information } \\
\text { Economy and company }\end{array}$ \\
\hline Low & $\begin{array}{ll}\text { Exact and natural sciences } \\
\text { Humanities }\end{array}$ & $\begin{array}{l}\text { Law and political sci- } \\
\text { ences }\end{array}$ \\
& Economy and company & \\
\hline
\end{tabular}

Source: In-house report

When we compare the above groups with the benefit groups from previous analyses from the same database, we can see that there is a certain connection. In both programs, the first two usage groups almost perfectly match the high-benefit group, and the last two match the low-benefit group.

In order to confirm it more analytically, the same linear regression was carried out, but substituting the 10 fields of study for 2 benefit groups. The results (Table 5) indicate that benefit is clearly linked to use. In this sense, for degree plans considered high-benefit, it is estimated at a 99\% significance level that there will be 0.3 more uses than those considered low-benefit, and
0.43 more uses in the virtual program, a higher result due to the atypical use of the Psychology and educational sciences department at this university. Therefore, we see that in the case of departments, as hypothesized, benefit and recognition of Internet-based interaction by the educational environment is a determinant in whether or not the students employ this Internet use.

Table 5. Differences in use by groups

\begin{tabular}{|c|c|}
\hline Benefit group & $\begin{array}{c}\begin{array}{c}\text { Estimated coefficients (standard } \\
\text { error) }\end{array} \\
\end{array}$ \\
\hline High-benefit & $\begin{aligned} & \text { Face-to-Face } \\
&+ 0.291^{* * *} \\
&(0.10)\end{aligned}$ \\
\hline
\end{tabular}

Source: In-house report

Note: Reference: low-benefit group

$* * *$ significant at $99 \%$

However, there is an exception to this connection worth mentioning. The case of Humanities degree plans in the virtual university. This department, despite being in the low-benefit group, is among the leaders in use. This indicates a very interesting result: In the case of degree plans with low returns on the job market (Carnoy, Jarillo, Castaño-Muñoz, DuartMontoliu, \& Sancho-Vinuesa, 2012), where students are not as preoccupied with completing their studies quickly in order to obtain benefits on the job market, benefit is not an important factor in determining use. In this sense, we see that use is higher whether or not the environment recognizes it. The explanation must be sought in another concept, and based on the student profile it seems as though that concept may be the motivation to learn.

The degree to which their studies are career-oriented is a significant variable in terms of explaining the benefit that the students obtain from Internet-based interaction (Castaño Muñoz et al., 2012), and following the proposed hypothesis, should also be significant in explaining Internet usage. Taking as a reference group the students that studied first and second-term (and therefore less career-oriented) degree plans, we see how at the face-to-face university, both second-term only and first-term only degree plans are estimated to increase interactive Internet usage in learning, with a significance level of 99\%. Furthermore, in the case of the virtual university we also see that second-term only degree plans use more than first-term only plans. We therefore see that in less career-oriented, longer degree plans, where interaction has been shown to be less beneficial, students use the Internet to a lesser extent for interactive learning. This would seem to confirm the hypothesis of benefit as a determinant of use (See Table 6).

By comparing the usage levels of students with first-term degree plans and those with second-term only degree plans, between which no type of significant differences were observed in terms of their benefit as measured by academic performance, we confirm that in the case of the face-to-face university there are no differences in terms of the intensity of its students' interactive practices. However, in the virtual university we do see some differences in favor of "second-term only" degree plans, with a significance level of $99 \%$ and a spot estimate of 0.104 more uses. Based on the fact that first-term and secondterm only degree plans are both career-oriented degree plans and benefit equally from interaction, the explanation for the fact that 
there are no differences between these degree plans at the faceto-face university, but there are in the virtual university, must be sought in the type of students from each university.

Table 6. Differences in use according to how career-oriented and how long the degree plan

\begin{tabular}{lll}
\hline Type of degree plan & \multicolumn{2}{c}{$\begin{array}{c}\text { Estimated coefficients } \\
\text { (standard error) }\end{array}$} \\
\hline \multirow{3}{*}{ First-term } & \multicolumn{1}{c}{ Face-to-Face } & \multicolumn{1}{c}{ Virtual } \\
& $0.277^{* * *}$ & Not comparable \\
Second-term & $(0.06)$ & \\
& $0.338^{* * *}$ & $0.275^{* * *}$ \\
& $(0.08)$ & $(0.04)$ \\
\hline
\end{tabular}

Source: In-house report

Note: Reference: "first and second-term” degree plans *** significant at $99 \%$

In the case of the virtual program, second-term students have an individual profile that, despite having completed a degree plan and being of a certain age (34 years on average), and therefore having had less time to collect on his/her investment in education, opts to study a specialized subject. Therefore, it is probably a profile more motivated by non-monetary benefits such as personal satisfaction, or for the sake of specializing in something and recycling knowledge that allows him/her to maintain good working status.

In the case of face-to-face universities, however, there is less difference between the second-term only student profile and that of a first-term only degree plan student. Second-term only students are more likely to look for incentives on the job market, given that they are relatively young students compared to the virtual program students (27 years on average; median 25 , mode $24)$, and are therefore at a point where studying more is very economically profitable, given the possibility of acquiring experience on the job market, and they have more years before they collect the benefits of their investment in education (Mincer, 1974).

Based on the above, the fact that there is only a difference between first-term only and second-term only degree plans in the virtual program appears to confirm that (following the same dynamic seen in the case of humanities in the virtual program) students motivated more by personal growth and less driven by the need to invest in their education in order to obtain economic benefit in the future, are students that interact most with their professors and classmates. This is very likely due to the fact that in part they receive the benefits of personal satisfaction from learning and participating in the teaching-learning process for its own sake (Kerka, 1988), and they see it less as an obligation to position themselves economically or pass the courses. For these students, the benefits lie more in the knowledge acquired and in enjoying the path leading to this knowledge (teaching-learning process), than in the application of that knowledge on the job market.

\section{CONCLUSIONS}

The analyses presented allow us to establish a series of exploratory correlations to gain more in-depth knowledge of the determinants of Internet use for interactive learning.

First of all, it must be said that, generally speaking, we have seen how the level of added benefit that certain students obtain (digital leaders in the virtual program, students on short, careeroriented degree plans in the face-to-face program, and students from specific departments) is linked to a higher intensity of use. Therefore, generally speaking, we may say that it fits the hypothesis that students to whom using the Internet for interaction is most useful are the ones that use it most. However, there are limitations:

- The students most skilled in Internet usage use this technology for interactive learning regardless of whether or not the environment in which they study recognizes this interaction

In virtual education, digital leaders, in spite of benefitting most from interactive Internet in terms of academic performance, do not have a higher intensity of use. The explanation for this is that the possibility of benefitting more from high usage abilities is only offered in educational environments highly favorable to technology, where interaction among all students is encouraged as part of the established teaching-learning process. But it is just this encouragement of use among all students that results in the same intensity of use for all students regardless of their Internet usage abilities, although students with greater ability are capable of receiving more benefit from the same intensity, given that they employ more sophisticated uses and they know how to optimize them.

- Motivation and use. In the virtual model, the students most motivated in learning make greater use of interactive Internet regardless of the benefit it offers them in terms of academic performance

There is higher Internet usage in career-oriented degree plans and in the departments that benefit most from using the Internet. However, there is evidence that in degree plans where the students study less for economic motivation and more for personal learning, there is higher Internet usage despite the fact that it is not especially valued in their field of study. This is reflected in the fact that the humanities students and the students in the $2^{\text {nd }}$-term of the virtual program have higher Internet usage than the usage that would match the added benefit they obtain.

- Cultures of gender and age and use

In regards to the socio-demographic variables, the proposed model has indicated that among the youngest students there is a greater trend toward interactive Internet usage. This fact reflects a cultural change in Internet usage, where young people are increasingly adopting online interaction as part of their lives and extrapolating this dynamic to learning. On the other hand, older students do not have this culture of online interaction and are inclined to traditional and unidirectional learning. Furthermore, age plays a role in the gender breach: women use interactive Internet for learning more, but only at older ages. This difference is not observed among the youth. This result coincides with the international evidence that posits that in the younger generations the digital gender breach is decreasing, and therefore certain uses are converging (OECD, 2007).

- Interpretative flexibility of the Internet and usage. The continuum between extracurricular uses and the intensity of use for interactive learning.

The analyses also show that, in the university system studied, uses employed outside of the classroom are also linked to higher or lower Internet usage for education in general, and also for interaction. In this sense, we have seen how the majority of extracurricular uses are linked to an increase in interactive Internet usage, but especially those that have a formal opposite 
of leisure and communicative component. Thus, using the Internet for email, work, and to post and share information outside of the classroom makes the student more inclined to use interaction inside the classroom. However, using it to download leisure content, to trade, or, only in the case of the youngest students, to hangout on chats and instant messaging services, have less influence.

From the perspective of equality on which the digital breach analysis is based, the analyses presented are important, since they allow us to identify the groups with less interactive Internet usage. If we want to broaden interactive Internet usage in an effective and egalitarian manner, some possible actions emerging from the data might be to:

Promote rewards for usage in the form of benefit. If Internet usage for interactive learning is incorporated into the evaluation systems for the types of degree plans and departments least inclined to use it, the students will use it more, and at the same time they will acquire an essential skill in this information society and achieve better learning outcomes.

Extend the interactive habit to groups that use it least, regardless of their skill level: older students, especially men.

Expand digital skills to a high level before encouraging interactive Internet usage. This way all students can be in conditions of higher use, or reap the maximum benefit from more technological environments.

Promote, among the youngest students, extracurricular Internet usage habits linked to communication and online work, without linking them only to leisure activities. In this manner, the students will bring their habits into the academic world.

\section{REFERENCES}

Beauchamp, G., \& Kennewell, S. (2010). Interactivity in the classroom and its impact on learning. Computers \& Education, 54(3), 759-766. doi: 10.1016/j.compedu.2009.09.033

Bernard, R. M., Abrami, P. C., Borokhovski, E., Wade, C. A., Tamim, R. M., Surkes, M. A., \& Bethel, E. C. (2009). A Meta-Analysis of Three Types of Interaction Treatments in Distance Education. Review of Educational Research, 79(3), 1243 -1289. doi: 10.3102/0034654309333844

Carnoy, M., Jarillo, B., Castaño-Muñoz, J., Duart-Montoliu, J. M., \& SanchoVinuesa, T. (2012). Does Virtual Higher Education Pay Off for Adult Learners? The Case of the Open University of Catalonia (UOC). Higher Education Quarterly, 63(3). doi: 10.1111/j.1468-2273.2012.00520.x

Castaño Muñoz, J., Sancho Vinuesa, T., \& Duart Montoliu, J. M. (2012). Internet en la universidad: ¿Quién se beneficia mas de la interaccion online? Paper presented at the XXI Jornadas de la Asociación de Economía de la Educación, Oporto. Retrieved from http://2012.economicsofeducation.com/user/pdfsesiones/071.pdf

Castaño-Muñoz, J., Duart, J. M., \& Sancho-Vinuesa, T. (2014). The Internet in face-to-face higher education: Can interactive learning improve academic achievement? British Journal of Educational Technology, 45(1) 149-159. doi: 10.1111/bjet.12007

Castaño-Muñoz, Jonatan. (2011). El uso de Internet para la Interacción en el aprendizaje: Un análisis de la eficacia y la igualdad en el sistema universitario catalán. Barcelona: Universitat Oberta de Catalunya. Retrieved from http://www.tesisenred.net/bitstream/handle/10803/52561/Tesis_Jonatan_Casta $\%$ C3\%B10.pdf?sequence $=1$

Davis, F. (1989). Perceived Usefulness, Perceived Ease of Use, and User Acceptance of Information Technology. MIS Quarterly, (Sept.), 319-339. doi: $10.2307 / 249008$

Davis, G., \& Venkatesh, V. (2003). User Acceptance of Information Technology: Toward a Unified View. Management Information Systems Quarterly, 27(3). Retrieved from http://aisel.aisnet.org/misq/vol27/iss3/5
Dimaggio, P., Hargittai, E., Celeste, C., \& Shafer, S. (2004). From unequal Access to Differentiated user Retrieved from http://citeseerx.ist.psu.edu/viewdoc/summary? doi: 10.1.1.85.6001

Hargittai, E., \& Walejko, G. (2008). THE - PARTICIPATION - DIVIDE: Content creation and sharing in the digital age. Information, Communication \& Society, 11(2), 239. doi: 10.1080/13691180801946150

Kerka, S. (1988). Strategies for Retaining Adult Students: The Educationally Disadvantaged. ERIC Digest No. 76. Retrieved from http://www.eric.ed.gov/ERICWebPortal/contentdelivery/servlet/ERICServlet?a ccno=ED299455

Means, B., Toyama, Y., Murphy, R., Bakia, M., \& Jones, K. (2009). Evaluation of Evidence-Based Practices in Online Learning: A Meta-Analysis and Review of Online Learning Studies. Washington, D. C.: U.S. Department od Education, Office of Planning, Evaluation, and Policy Development. Retrieved from http://www2.ed.gov/rschstat/eval/tech/evidence-based-practices/finalreport.pdf

Mincer, J. (1974). Schooling, Experience, and Earnings. Columbia University Press. Retrieved from http://www.nber.org/books/minc74-1

OCDE. (2007). ICTs and Gender. Working Party on the Information Economy. OECD; Directorate for Science, Technology and Industry. Committee for Information, Computer and Communication Policy. Retrieved from http://www.oecd.org/dataoecd/16/33/38332121.pdf

Premsky, M. (2001). Digital natives, digital Immigrants. On the Horizon, 9(5). Retrieved from http://www.marcprensky.com/writing/Prensky\%20\%20Digital\%20Natives,\%20Digital\%20Immigrants\%20-\%20Part1.pdf

Robles-Morales, J. M., Torres-Albero, C., \& Molina-Molina, Ó. (2010). Las Fuentes de las Desigualdades Tecnológicas en España: Un Estudio Sobre las Nuevas Formas de Desigualdad Social. Sistema, 218, 3-22.

Van Dijk, J. (2005). The deepening divide: inequality in the information society. Thousand Oaks, California: Sage Pub.

Van Dijk, J., \& Hacker, K. (2003). The Digital Divide as a Complex and Dynamic Phenomenon. The Information Society: An International Journal, 19(4), 315. doi: 10.1080/01972240309487

Wilson, G., \& Stacey, E. (2003). Online Interaction Impacts on learning: teaching the teachers to teach online. Paper presented at the 20th Annual Conference of the Australian Society for Computers in Learning in Tertiary Education (ASCILITE), Adelaide, Australia.

Zhao, Y., Lei, J., Yan, B., Lai, C., \& Tan, H. S. (2005). What Makes the Difference? A Practical Analysis of Research on the Effectiveness of Distance Education. Teachers College Record, 107(8), 1836-1884. doi: 10.1111/j.14679620.2005.00544.x

Zillien, N., \& Hargittai, E. (2009). Digital Distinction: Status-Specific Types of Internet Usage. Social Science Quarterly, 90(2), 274-291. doi: 10.1111/j.15406237.2009.00617.x 